\title{
Ocena kardiologiczna pacjentów z niewydolnością wątroby w ramach kwalifikacji do operacji przeszczepienia wątroby
}

\author{
Cardiac assessment of patients with liver failure \\ in the evaluation program before liver transplantation
}

\author{
Michalina Galas, Renata Główczyńska, Gabriela Parol \\ I Katedra i Klinika Kardiologii Warszawskiego Uniwersytetu Medycznego
}

\section{Streszczenie}

Przeszczepienie wątroby to bardzo inwazyjna, rozległa i wielogodzinna operacja klasyfikowana według Europejskiego Towarzystwa Kardiologicznego do operacji najwyższego ryzyka sercowo-naczyniowego, co oznacza ponad 5-procentowe ryzyko zgonu z powodów sercowych lub zawału serca w okresie 30 dni po zabiegu. Jednocześnie niewydolność wątroby istotnie zaburza funkcję układu sercowo-naczyniowego. Nadciśnienie wrotne wiąże się z obecnością krążenia hiperkinetycznego, którego powikłaniem jest kardiomiopatia wątrobowa. Poważną konsekwencją choroby wątroby może być również rozwój zespołu wątrobowo-płucnego. Celem właściwej oceny kardiologicznej tej grupy pacjentów jest wczesne rozpoznanie specyficznych patologii układu sercowo-naczyniowego, co stanowi niezbędny element zarówno procesu kwalifikacji kandydata do przeszczepienia narządu, jak i ważną informację dla interdyscyplinarnego zespołu lekarskiego o zwiększonym ryzyku powikłań w trudnym okresie okołooperacyjnym.

Słowa kluczowe: diagnostyka, kardiomiopatia wątrobowa, niewydolność wątroby

Folia Cardiologica 2017; 12, 2: 220-227

\section{Wstęp}

Przeszczepienie wątroby to bardzo inwazyjna, rozległa i wielogodzinna operacja klasyfikowana wg Europejskiego Towarzystwa Kardiologicznego do operacji najwyższego ryzyka sercowo-naczyniowego, co oznacza ponad 5-procentowe ryzyko zgonu z powodów sercowych lub zawału serca w ciągu 30 dni od operacji [1]. Jednocześnie niewydolność wątroby istotnie zaburza funkcję układu krążenia. Nadciśnienie wrotne wiąże się z obecnością krążenia hiperkinetycznego, którego powikłaniem jest kardiomiopatia wątrobowa (CCM, cirrhotic cardiomyopathy). Poważną konsekwencją choroby wątroby może być również rozwój zespołu wątrobowo-płucnego (HPS, hepatopulmonary syndrome). Właściwa ocena kardiologiczna tej grupy pacjentów ma na celu wczesne rozpoznanie specyficznych patologii układu krążenia, co jest niezbędnym elementem zarówno w procesie kwalifikacji kandydata do przeszczepienia narządu oraz ważną informacją dla interdyscyplinarnego zespołu lekarskiego o zwiększonym ryzyku powikłań w trudnym okresie okołooperacyjnym.

\section{Metody diagnostyczne}

Metody diagnostyczne podano w tabeli 1 [2].

\section{Badanie elektrokardiograficzne}

Obecność krążenia hiperkinetycznego i częste występowania tachykardii, w szczególności w zaawansowanym stadium choroby, może utrudniać rzeczywistą ocenę skorygowanego do częstości rytmu serca odstępu QT. Wzór Bazetta,

Adres do korespondencji: dr n. med. Renata Główczyńska, I Katedra i Klinika Kardiologii, Warszawski Uniwersytet Medyczny, Centralny Szpital Kliniczny, ul. Banacha 1a, 02-097 Warszawa, e-mail: renata.glowczynska@wum.edu.pl 
Tabela 1. Zalecane metody diagnostyczne (zmodyfikowano na podstawie [2])

\begin{tabular}{|c|c|}
\hline Metoda diagnostyczna & Możliwe nieprawidłowości \\
\hline EKG & Wydłużony odstęp QT \\
\hline Test wysiłkowy & Zmniejszona wydolność wysiłkowa \\
\hline Ergospirometria & Nieprawidłowe $\mathrm{VO}_{2}$ peak, VE/ $\mathrm{VCO}_{2}$ slope \\
\hline 6MWT & Zmniejszona tolerancja wysiłku (zmniejszony dystans) \\
\hline Echokardiografia przezklatkowa & $\begin{array}{l}\text { LVEF }<55 \% \\
\text { Dysfunkcja rozkurczowa (E/E' > 10) }\end{array}$ \\
\hline Próba dobutaminowa & Zmniejszona rezerwa kurczliwości \\
\hline CMR & $\begin{array}{l}\text { LVEF }<55 \% \\
\text { Dysfunkcja rozkurczowa }\left(E / E^{\prime}>10\right)\end{array}$ \\
\hline Biomarkery & Podwyższone stężenie Tn I i NT-proBNP (lub BNP) \\
\hline
\end{tabular}

E/E' - stosunek maksymalnej prędkości wczesnej (rozkurczowej) fali napływu mitralnego (mierzonej za pomocą doplera pulsacyjnego) do wczesnorozkurczowej prędkości ruchu pierścienia mitralnego (mierzonej za pomoca tkankowego badania doplerowskiego) stosowany jako wskaźnik podwyższonego ciśnienia napełniania lewej komory; $\mathrm{VO}_{2}$ peak - szczytowe pochłanianie tlenu; VE/VCO, ${ }_{2}$ slope - współczynnik regresji linowej zależności wentylacji minutowej od ilości wydalanego dwutlenku węgla; EKG - badanie elektrokardiograficzne; 6MWT (6-minute walk test) - test 6-minutowego marszu; CMR (cardiovascular magnetic resonance) - rezonans magnetyczny serca; LVEF (left ventricular ejection fraction) - frakcja wyrzutowa lewej komory; Tn I (troponin I) - troponina I; NT-proBNP (N-terminal pro-B-type natriuretic peptide) - N-końcowy propeptyd natriuretyczny typu B; BNP (B-type natriuretic peptide) - peptyd natriuretyczny typu B

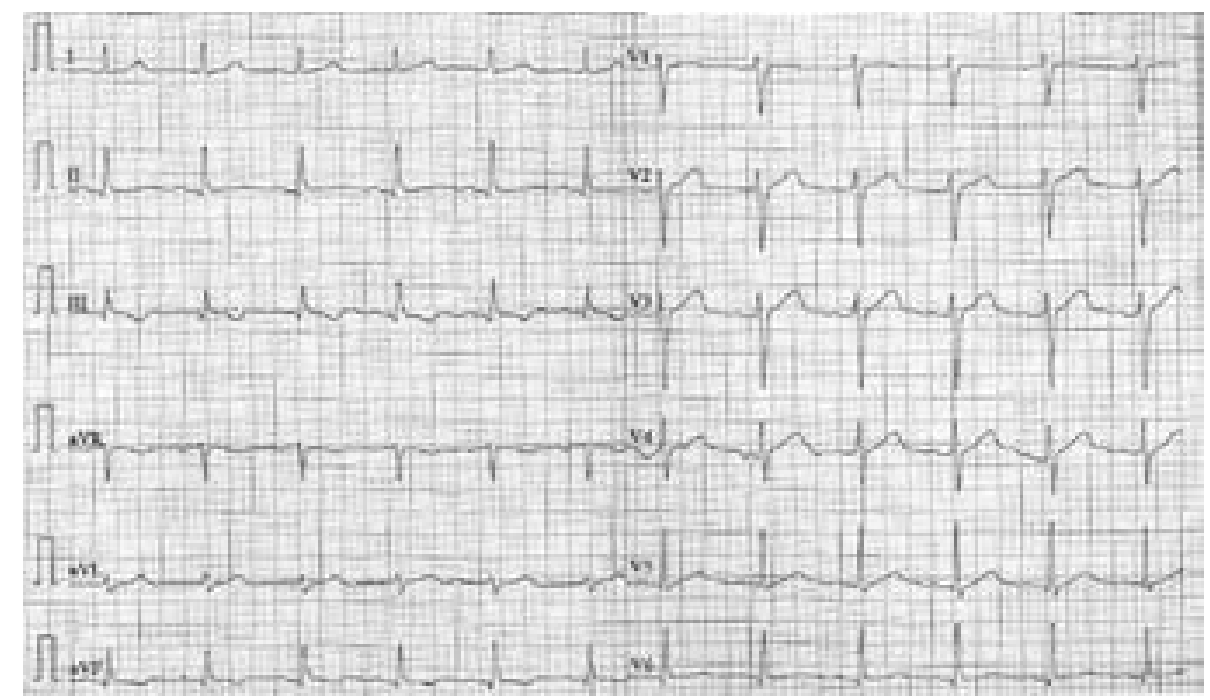

Rycina 1. Zapis elektrokardiograficzny z wydłużeniem odstępu QT; RR 882 ms, odstęp QT 443 ms, QTc według wzoru Bazetta 472 ms, QTc według wzoru Fridericia 462 ms, QTc według wzoru Framingham 462 ms, QTc według wzoru Hodgesa 457 ms

najczęściej stosowany w tej sytuacji klinicznej i zalecany dla rytmów o częstości 60-100/min, zawyża długość QTc. W celu uniknięcia niewłaściwej oceny elektrokardiograficznej (EKG) proponuje się, aby do wyliczenia skorygowanego odstępu QT u chorych z marskością wątroby stosować inne wzory, na przykład wzór Fridericia $\left(\mathrm{QTC}=\mathrm{QT} / \mathrm{RR}^{1 / 3}\right.$ ) lub formułę przeznaczoną dla pacjentów z marskością wątroby $\left(\mathrm{QTc}=453,65 \times \mathrm{RR}^{1 / 3,02}\right)$ [3], które w mniejszym stopniu zależą od długości odstępów RR niż wzór Bazetta. Niestety, w wielu publikacjach widoczna jest dowolność zarówno w odniesieniu do wyboru formuły obliczeń, jak i kryteriów rozpoznania wydłużonego odstępu QT u kobiet (QT > 460 ms) i mężczyzn (QT > 440 ms). Brak jednolitych kryteriów diagnostycznych skutkuje rozbieżnością w rozpoznawaniu wydłużonego zespołu QT, a różnice wynikające z zastosowania formuł Bazetta, Fridericia i formuły zaproponowanej przez Zambruni i wsp. [3] wynoszą około $10 \mathrm{~ms}$. W najnowszych badaniach, w których wykorzystywano formułę Fridericia, odsetek osób z wydłużeniem odstępu QT zmniejszył się do 19\% [3].

Na rycinie 1 przedstawiono zapis EKG 45-letniego mężczyzny z pozapalną marskością wątroby w klasie $B$ według klasyfikacji Child-Pugh, kwalifikowanego do przeszczepienia wątroby.

\section{Echokardiografia}

Badanie echokardiograficzne jest podstawową metodą wykrywania dysfunkcji skurczowej i rozkurczowej mięśnia sercowego niezbędnych do rozpoznania CCM. Do naj- 
częstszych odchyleń opisywanych w populacji pacjentów z marskością należą przerost mięśnia sercowego, powiększenie lewego przedsionka (LA, left atrium) i lewej komory (LV, left ventricle) serca [4]. U pacjentów z niewydolnością wątroby powiększenie LA ma charakter wieloczynnikowy i nie zawsze odzwierciedla podwyższone ciśnienie napełniania LV. Zwiększony wymiar LA nie jest zatem obecnie traktowany jako marker lewokomorowej dysfunkcji rozkurczowej w tej grupie chorych [5].

U chorych z marskością wątroby, nawet z CCM, obniżenie frakcji wyrzutowej lewej komory (LVEF, left ventricular ejection fraction) stwierdza się stosunkowo rzadko w badaniu spoczynkowym, co jest wynikiem obecności krążenia hiperkinetycznego. W celu rozpoznania utajonej dysfunkcji skurczowej niektórzy badacze proponują wykonywanie obciążeniowego badania echokardiograficznego. Brak wzrostu LVEF o 10\% względem wartości spoczynkowych podczas próby dobutaminowej świadczy o nieprawidłowej odpowiedzi skurczowej na obciążenie i w przypadku pacjentów z marskością wątroby może wynikać z CCM, pod warunkiem braku innej choroby układu sercowo-naczyniowego [6]. Ze względu na zróżnicowaną etiologię zmniejszonej rezerwy kurczliwości testy obciążeniowe w tej grupie chorych mają obniżoną wartość diagnostyczną w ocenie niedokrwienia mięśnia sercowego [7].

Podstawowe zastosowanie do oceny zaburzeń funkcji rozkurczowej LV mają techniki doplerowskie, a wybrane parametry stanowią czułe markery dysfunkcji rozkurczowej związanej z nadciśnieniem tętniczym, cukrzycą, chorobą niedokrwienną serca i potencjalnie z CCM [8]. Wielu autorów rozpoznawało dysfunkcję rozkurczową, a tym samym CCM, w przypadku spełnienia jedynie kryterium stosunku prędkości wczesnej fali napływu mitralnego do prędkości fali przedsionkowej (E/A) wynoszącego ponad 1, co jednak wydaje się błędem. Wśród pozostałych kryteriów opisujących funkcję rozkurczową LV w roboczej definicji CCM wymienia się również czas rozkurczu izowolumetrynczego przekraczający 80 ms oraz wydłużenie czasu deceleracji fali E powyżej 200 ms. W aktualnych wytycznych Europejskiego Towarzystwa Kardiologicznego (ESC, European Society of Cardiology) oraz wytycznych Amerykańskiego Towarzystwa Echokardiografii (ASE, American Society of Echocardiography) proponuje się bardziej skomplikowane algorytmy rozpoznawania dysfunkcji rozkurczowej z wykorzystaniem szerszej gamy parametrów echokardiograficznych niż wymienione powyżej. Świadczy to o dużym uproszczeniu i dezaktualizacji roboczej definicji CCM. Najnowsze statystyki wskazują, że wśród pacjentów z marskością wątroby dominuje łagodna dysfunkcja rozkurczowa i dotyczy blisko 36\% chorych, w tym u 71,1\% stwierdzono 1. stopień, u kolejnych 26,3\% - 2. stopień, a jedynie u 2,6\% pacjentów występowały poważne zaburzenia funkcji rozkurczowej (3. stopień) [9].

Sugeruje się, aby marker CCM stanowił stosunek prędkości napływu mitralnego i prędkości pierścienia mitralnego we wczesnej fazie rozkurczu (E/E') powyżej 10 [10].

Na rycinie 2 ukazano wynik obrazowania echokardiograficznego pacjentki ze schyłkową niewydolnością wątroby w przebiegu autoimmunologicznego zapalenia wątroby.
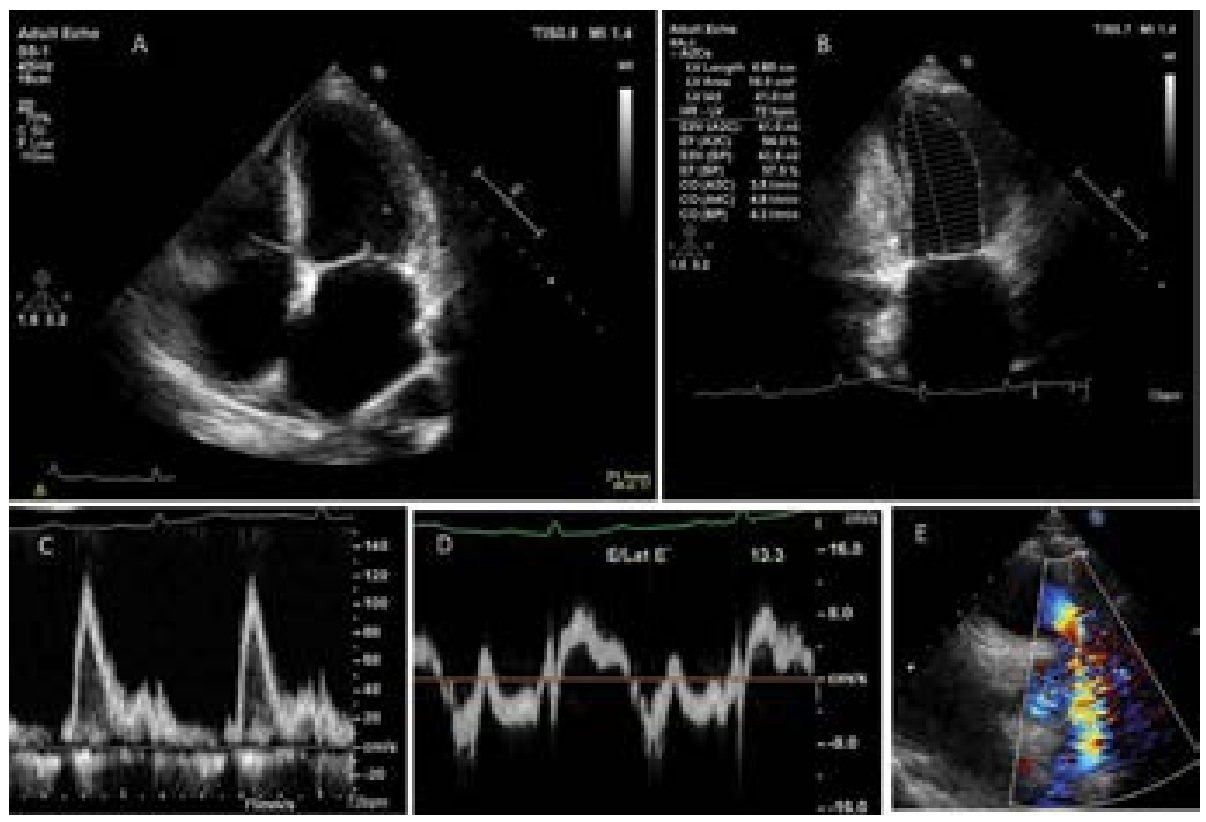

Rycina 2A-E. Badanie echokardiograficzne 45-letniej pacjentki ze schyłkową niewydolnością wątroby w przebiegu autoimmunologicznego zapalenia wątroby. Widoczne istotna dysfunkcja rozkurczowa i cechy krążenia hiperdynamicznego: A. Projekcja koniuszkowa 4-jamowa, powiększony lewy przedsionek; B. Projekcja koniuszkowa 2-jamowa, frakcja wyrzutowa (EF, ejection fraction) 57\%, CO 4,3 I/min; C. Doppler fali pulsacyjnej napływu mitralnego, restrykcyjny profil mitralny; D. Echokardiografia tkankowa, stosunek E/E' 13,3 (na wysokości bocznej części pierścienia mitralnego); E. Turbulentny przepływ w pniu płucnym 


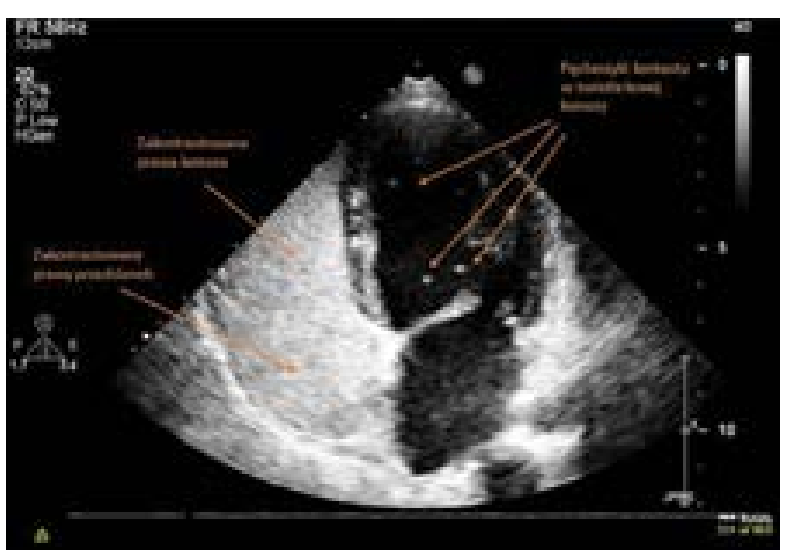

Rycina 3. Projekcja koniuszkowa 4-jamowa - uwidocznione przechodzenie pęcherzyków kontrastu na lewą połowę serca po 6 cyklach pracy serca u 47-letniego mężczyzny z alkoholową marskością wątroby

Oprócz klasycznych parametrów obrazowania 2-wymiarowego spektralną techniką doplerowską w rozpoznawaniu dyskretnych odchyleń bardziej czułe są techniki echokardiograficzne. Metody tkankowej echokardiografii doplerowskiej (TDE, transesophageal Doppler echocardiography) i wyznaczenie tempa odkształcania miokardium (SR, strain rate) mogą być przydatne w rozpoznawaniu subklinicznej dysfunkcji skurczowej LV. Ostatnie badania wskazują na obniżoną szczytową prędkość skurczową miokardium i zwiększone szczytowe tempo odkształcania LV u pacjentów z marskością wątroby w porównaniu z grupą kontrolną. Coraz większe nadzieje w rozpoznawaniu CCM wiąże się z badaniem oceny SR i techniką śledzenia markerów akustycznych [11].

Badanie kontrastowe z podaniem spienionej soli fizjologicznej do układu żylnego i stwierdzenie obecności mikropęcherzyków powietrza w jamach lewego serca po ponad 6 cyklach pracy serca stanowi jedno z kryterium rozpoznania HPS. Jest to kolejne powikłanie hepatopatii determinujące przeżywalność pacjentów.

Rycina 3 obrazuje przechodzenie pęcherzyków kontrastu na lewą połowę serca po 7 cyklach pracy serca.

Badanie echokardiograficzne umożliwia nieinwazyjną ocenę ciśnienia w tętnicy płucnej i prawej komorze, dlatego jest pomocne w diagnostyce nadciśnienia wrotno-płucnego (PPH, porto-pulmonary hypertension). Problem ten dotyczy od $4,5 \%$ do $8,5 \%$ chorych z zaawansowana niewydolnością wątroby [12]. Podejrzenie PPH wymaga potwierdzenia w cewnikowaniu prawego serca.

\section{Biomarkery}

Wzrost stężenia troponiny I często się zdarza u pacjentów z marskością wątroby, co wskazuje na subkliniczne uszko- dzenia miokardium i może się wiązać z obniżeniem objętości wyrzutowej LV oraz zmniejszeniem wskaźnika masy LV [13].

Peptydy natriuretyczne (przedsionkowy peptyd natriuretyczny [ANP, atrial natriuretic peptide] i peptyd natriuretyczny typu B [BNP, B-type natriuretic peptide]) są czułymi markerami uszkodzenia mięśnia sercowego, a ich stężenie koreluje z zaawansowaniem marskości wątroby, stopniem dysfunkcji LV, przerostem miokardium i rokowaniem. Wzrost wartości tych peptydów odzwierciedla przerost i dysfunkcję LV, dlatego ich oznaczenie może być użyteczne jako badanie przesiewowe w kierunku CCM $[14,15]$.

U pacjentów z wodobrzuszem dochodzi do powiększenia prawego przedsionka, spowodowanego między innymi przeciążeniem objętościowym, wtórnym do zwiększonej objętości krwi krążącej. Stężenie ANP wydzielanego przez nadmiernie rozciągane kardiomiocyty przedsionków jest zwykle podwyższone u chorych ze zdekompensowaną marskością wątroby.

Wzrost stężenia NT-proBNP zależy od stopnia zaawansowania niewydolności wątroby, dlatego jest ono najwyższe u chorych w klasie $C$ według klasyfikacji Child-Pugh, z wysoką punktacją w skali MELD (Model of End-Stage Liver Disease) oraz u pacjentów z wodobrzuszem [16]. Nieprawidłowe stężenie NT-proBNP może być przydatne w identyfikacji pacjentów obarczonych podwyższonym ryzykiem sercowo-naczyniowym, a tym samym - gorszym rokowaniem. U pacjentki, której obraz echokardiograficzny przedstawia rycina 2, stężenie NT-proBNP wynosiło 543 pg/ml.

\section{Sercowo-płucny test wysiłkowy}

Sercowo-płucny test wysiłkowy (CPET, cardiopulmonary exercise test), polegający na analizie gazów oddechowych podczas narastającego wysiłku, jest źródłem wielu cennych danych o funkcji układu sercowo-naczyniowego, układu oddechowego oraz przemian metabolicznych. Umożliwiając ocenę maksymalnego pochłaniania tlenu na szczycie wysiłku $\left(\mathrm{VO}_{2}\right.$ peak) jest doskonałym narzędziem oceny wydolności fizycznej. Pacjentów z niewydolnością wątroby cechuje obniżona wydolność fizyczna, a zmniejszone pochłanianie tlenu na szczycie wysiłku może wynikać z wielu powikłań choroby, takich jak niedożywienie, osłabienie mięśni, niedokrwistość, obecności CCM czy HPS. Spadek wartości szczytowego $\mathrm{VO}_{2}$ koreluje z zaawansowaniem marskości wątroby, ocenianej za pomocą punktacji w skalach MELD i Child-Pugh, charakteryzując się dalszym, stopniowym zmniejszaniem u pacjentów ze schyłkową marskością wątroby.

Wydolność fizyczna jest silnym, niezależnym predyktorem zgonu niezależnie od przyczyny. Szczytowe pochłanianie tlenu jest szeroko stosowanym parametrem pomocnym przy kwalifikowaniu kandydatów do transplantacji serca, płuc oraz programów rehabilitacji, a - jak wykazano w ostatnich badaniach - jego niska wartość 


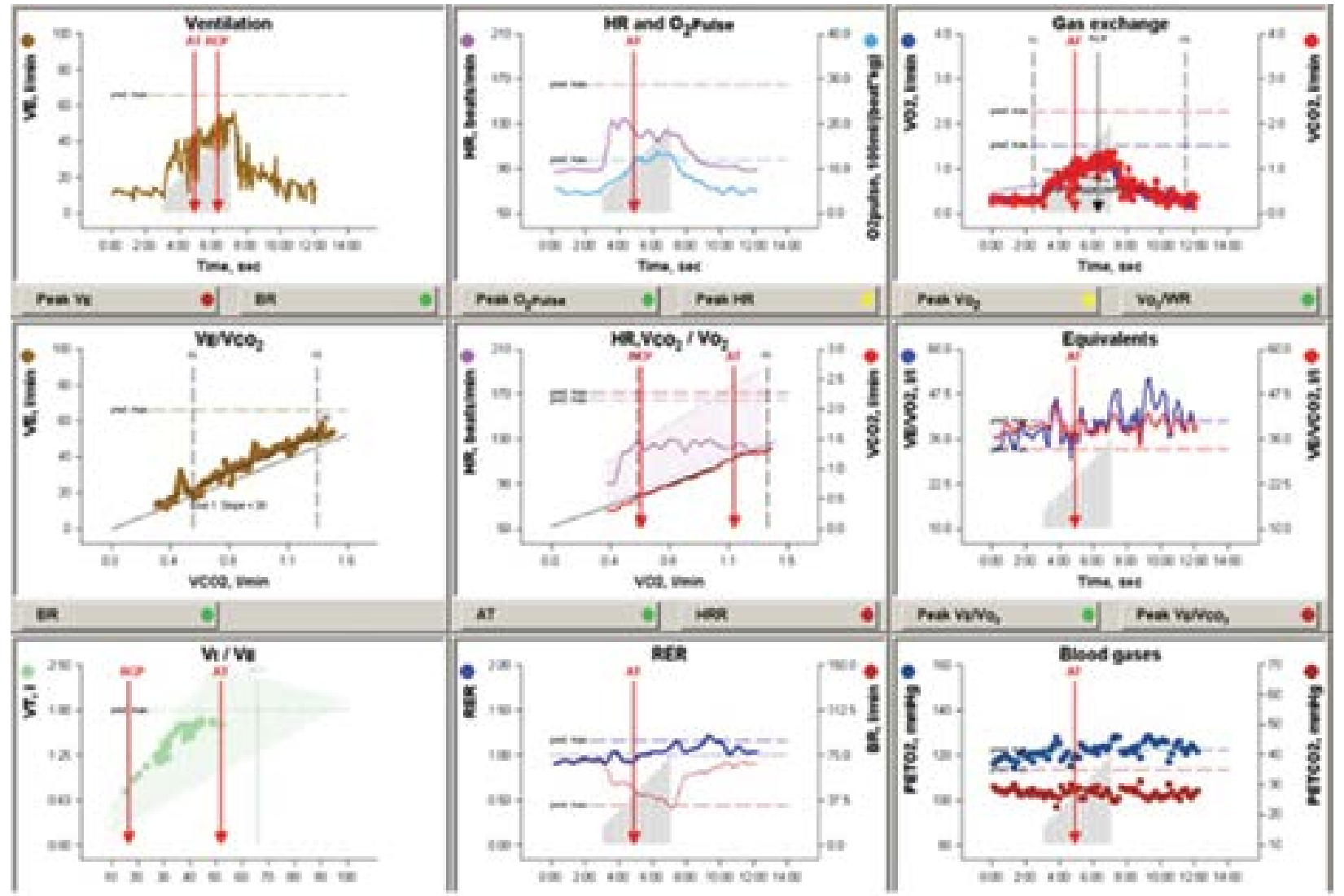

Rycina 4. Badanie ergospirometryczne 60-letniej pacjentki bez wywiadu chorób układu sercowo-naczyniowego z niewydolnością wątroby o etiologii wirusowej (wirus zapalenia wątroby typu C [HCV, hepatitis C virus] i wirus zapalenia wątroby typu B [HBV, hepatitis B virus]) powikłaną rakiem wątrobowo-komórkowym (HCC, hepatocellular carcinoma), czas wysiłku 4 min i 3 s; badanie wskazuje na obniżoną wydolność wysiłkową - klasa wydolnościowa C według Webera $\left(\mathrm{VO}_{2}\right.$ peak 15,6 ml/kg mc./min = 81\% normy); III klasa wentylacyjna $\left(\mathrm{VE} / \mathrm{VCO}{ }_{2}\right.$ slope 38) (wykres Wassermana nr 4); widoczna nadmierna wysiłkowa oscylacja wentylacji (wykres Wassermana nr 1); nieadekwatna odpowiedź chronotropowa na wysiłek (wykres Wassermana $\mathrm{nr}$ 5); $\mathrm{VO}_{2}$ peak - szczytowe pochłanianie tlenu; VE/ $\mathrm{VCO}_{2}$ slope - współczynnik regresji linowej zależności wentylacji minutowej od ilości wydalanego dwutlenku węgla

wiąże się ze zwiększonym ryzykiem zgonu u pacjentów po przeszczepieniu wątroby [17-19]. Również w badaniu ergospirometrycznym obserwuje się nieprawidłowości u pacjentów z HPS [20].

Na rycinie 4 przedstawiono dziewięć wykresów Wassermana u 60-letniej pacjentki z niewydolnością wątroby o etiologii wirusowej.

\section{Rezonans magnetyczny}

Obrazowanie metodą rezonansu magnetycznego (MRI, magnetic resonance imaging) jest doskonałą metodą zarówno w ocenie morfologicznej, jak i czynnościowej mięśnia sercowego, stanowiąc wartościowe uzupełnienie badania echokardiograficznego, zwłaszcza gdy jest ono ograniczone trudnymi warunkami technicznymi obniżajacymi jakość badania, na przykład u osób otyłych [21, 22]. Badanie MRI wnosi ponadto dodatkowe informacje o patologiach struktury, jakimi są obrzęk i włóknienie miokardium występujące w CCM. Obserwacja całego cyklu pracy serca z wykorzystaniem różnych opcji badania, na przykład myocardial tagging, umożliwia precyzyjną analizę czynnościową serca w tym ocenę zaburzeń kurczliwości lewej komory, dlatego ma potencjał wykrywania subklinicznych zmian przed pojawieniem się jawnej niewydolności serca. Zastosowanie MRI wydaje się pomocne w identyfikacji pacjentów z marskością wątroby zagrożonych rozwojem niewydolności serca, jednak obecnie rozpowszechnienie diagnostyki tą metodą ograniczają jej mała dostępność i wysoki koszt.

\section{Podsumowanie}

W ostatnio zaproponowanym przez Zardi i wsp. [23] algorytmie postępowania diagnostycznego (ryc. 5) u pacjentów z marskością wątroby badanie ergospirometryczne jest na pierwszej pozycji jako badanie, które pozwala ocenić nie tylko wydolność wysiłkową, ale również odpowiedź chronotropową. Poszczególne parametry ergospirometry- 


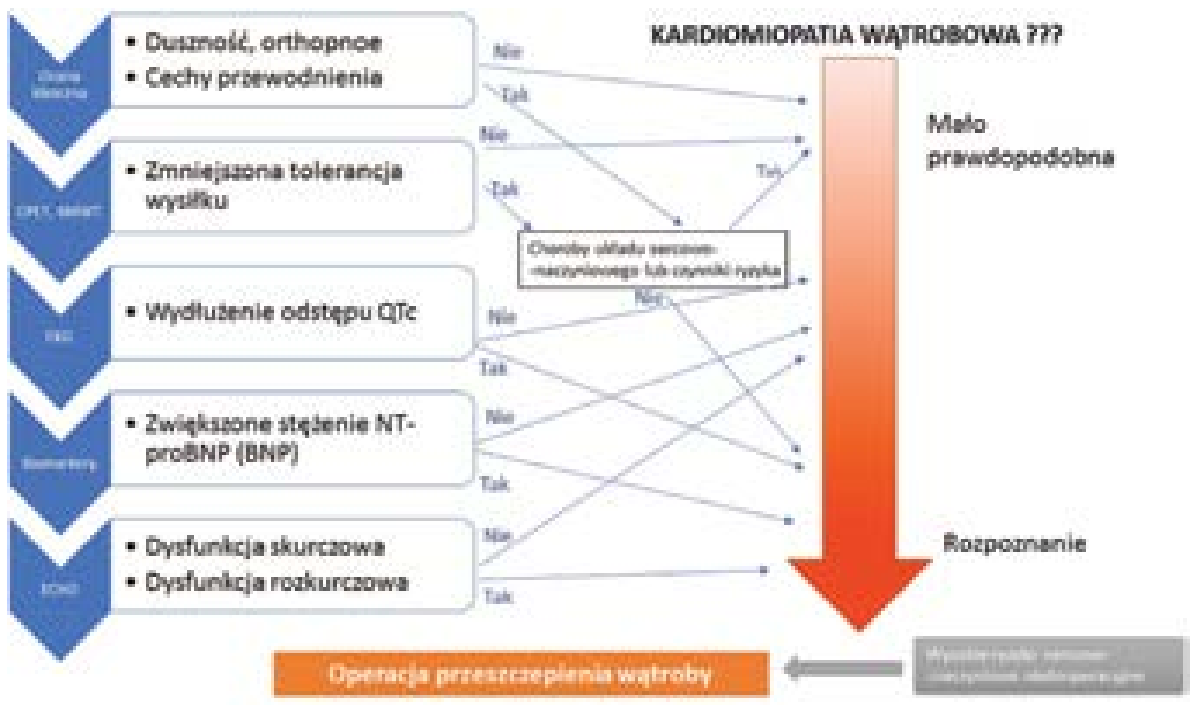

Rycina 5. Zalecany algorytm diagnostycznych w kierunku kardiomiopatii wątrobowej u pacjentów kwalifikowanych do operacji przeszczepienia wątroby; CPET (cardiopulmonary exercise test) - sercowo-płucny test wysiłkowy; 6MWT (6-minute walk test) - test 6-minutowego marszu; EKG - badanie elektrokardiograficzne; ECHO - badanie echokardiograficzne; NT-proBNP (N-terminal pro-B-type natriuretic peptide) - N-końcowy propeptyd natriuretyczny typu B; BNP (B-type natriuretic peptide) - peptyd natriuretyczny typu B

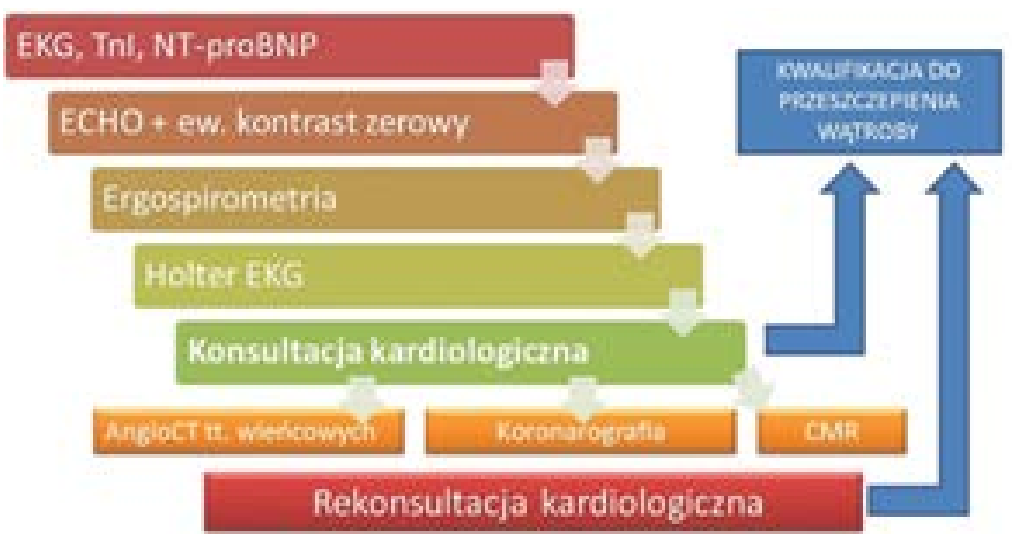

Rycina 6. Algorytm oceny kardiologicznej pacjentów kwalifikowanych do operacji przeszczepienia wątroby w Centralnym Szpitalu Klinicznym w Warszawie; EKG - badanie elektrokardiograficzne; Tnl (troponin I) - troponina I; NT-proBNP (N-terminal pro-B-type natriuretic peptide) - N-końcowy propeptyd natriuretyczny typu B; CT (computed tomography) - tomografia komputerowa; tt. - tętnice; CMR (cardiovascular magnetic resonance) - rezonans magnetyczny serca

czne wykazują wartość prognostyczną i mogą być pomocne w rozpoznawaniu CCM.

W I Katedrze i Klinice Kardiologii Warszawskiego Uniwersytetu Medycznego zaproponowaliśmy autorski algorytm konsultacji kardiologicznych u wszystkich potencjalnych kandydatów do przeszczepienia wątroby. Algorytm ten odpowiada aktualnym zaleceniom i jest stosowany w Centralnym Szpitalu Klinicznym od maja 2013 roku (ryc. 6).

\section{Konflikt interesów}

Autorki deklarują brak konfliktu interesów. 


\section{Abstract}

Liver transplantation is assumed to be a very invasive, extensive and long-lasting surgery, classified, according to the European Society of Cardiology, as a surgery of the highest cardiovascular risk with 5 percent risk of cardiovascular death and myocardial infarction within 30 days after surgery. Liver failure is associated with cardiovascular complications of cirrhosis including cardiac dysfunction and abnormalities in the central, peripheral and splanchnic circulation and some haemodynamic changes. Portal hypertension is accompanied with the hyperkinetic circulation, which results in complications such as cirrhotic cardiomyopathy. Hepatopulmonary syndrome is also a result of liver disease. The aim of the cardiac assessment in this group of patients is an early identification of the specific cardiovascular pathologies. This constitutes an essential element of the qualification process of candidates for transplantation and important information about the increased risk of complications during the perioperative period for an interdisciplinary team.

Key words: cardiac assessment, cirrhotic cardiomyopathy, liver failure

Folia Cardiologica 2017; 12, 2: 220-227

\section{Piśmiennictwo}

1. Poldermans D, Bax JJ, Boersma E, et al. Grupa Robocza Europejskiego Towarzystwa Kardiologicznego (ESC) do spraw oceny ryzyka sercowego oraz okołooperacyjnego postępowania kardiologicznego u pacjentów poddawanych zabiegom niekardiologicznym, we współpracy z Europejskim Towarzystwem Anestezjologicznym (ESA). Wytyczne Europejskiego Towarzystwa Kardiologicznego dotyczące przedoperacyjnej oceny ryzyka sercowego oraz okołooperacyjnego postępowania kardiologicznego u pacjentów poddawanych zabiegom niekardiologicznym. Kardiol. Pol. 2010; 68. ; 3(supl. 2): S53-S108.

2. Zardi EM, Zardi DM, Chin D, et al. Cirrhotic cardiomyopathy in the preand post-liver transplantation phase. J Cardiol. 2016; 67(2): 125-130, doi: 10.1016/j.jjcc.2015.04.016, indexed in Pubmed: 26074443.

3. Zambruni A, Di Micoli A, Lubisco A, et al. QT interval correction in patients with cirrhosis. J Cardiovasc Electrophysiol. 2007; 18(1): 77-82, doi: 10.1111/j.1540-8167.2006.00622.x, indexed in Pubmed: 17229304.

4. Gassanov N, Caglayan E, Semmo N, et al. Cirrhotic cardiomyopathy: a cardiologist's perspective. World J Gastroenterol. 2014; 20(42): 15492-15498, doi: 10.3748/wjg.v20.i42.15492, indexed in Pubmed: 25400434.

5. Sampaio F, Pimenta J, Bettencourt N, et al. Left atrial function is impaired in cirrhosis: a speckle tracking echocardiographic study. Hepatol Int. 2014; 8(1): 146-153, doi: 10.1007/s12072-013-9469-5, indexed in Pubmed: 26202416.

6. Naqvi IH, Mahmood K, Naeem M, et al. The heart matters when the liver shatters! Cirrhotic cardiomyopathy: frequency, comparison, and correlation with severity of disease. Prz Gastroenterol. 2016; 11(4): $247-$ -256, doi: 10.5114/pg.2016.57962, indexed in Pubmed: 28053679.

7. Harinstein ME, Flaherty JD, Ansari AH, et al. Predictive value of dobutamine stress echocardiography for coronary artery disease detection in liver transplant candidates. Am J Transplant. 2008; 8(7): 1523-1528, doi: 10.1111/j.1600-6143.2008.02276.x, indexed in Pubmed: 18510630.

8. Møller S, Hove JD, Dixen U, et al. New insights into cirrhotic cardiomyopathy. Int J Cardiol. 2013; 167(4): 1101-1108, doi: 10.1016/j. ijcard.2012.09.089, indexed in Pubmed: 23041091.
9. Wong F, Villamil A, Merli M, et al. Prevalence of diastolic dysfunction in cirrhosis and its clinical significance. Hepatology. 2011; 54: 475A.

10. Møller S, Wiese S, Halgreen $\mathrm{H}$, et al. Diastolic dysfunction in cirrhosis. Heart Fail Rev. 2016; 21(5): 599-610, doi: 10.1007/s10741-0169552-9, indexed in Pubmed: 27075496.

11. Kazankov K, Holland-Fischer P, Andersen NH, et al. Resting myocardial dysfunction in cirrhosis quantified by tissue Doppler imaging. Liver Int. 2011; 31(4): 534-540, doi: 10.1111/j.1478-3231.2011.02468.x, indexed in Pubmed: 21382164.

12. Cartin-Ceba R, Krowka MJ. Portopulmonary hypertension. Clin Liver Dis. 2014; 18(2): 421-438, doi: 10.1016/j.cld.2014.01.004, indexed in Pubmed: 24679504.

13. Pateron D, Beyne P, Laperche $T$, et al. Elevated circulating cardiac troponin I in patients with cirrhosis. Hepatology. 1999; 29(3): 640-643, doi: 10.1002/hep.510290332, indexed in Pubmed: 10051461.

14. Henriksen JH, Gøtze JP, Fuglsang $S$, et al. Increased circulating probrain natriuretic peptide (proBNP) and brain natriuretic peptide (BNP) in patients with cirrhosis: relation to cardiovascular dysfunction and severity of disease. Gut. 2003; 52(10): 1511-1517, indexed in Pubmed: 12970147.

15. Saner FH, Neumann T, Canbay A, et al. High brain-natriuretic peptide level predicts cirrhotic cardiomyopathy in liver transplant patients. Transpl Int. 2011; 24(5): 425-432, doi: 10.1111/j.14322277.2011.01219.x, indexed in Pubmed: 21276088.

16. Licata A, Corrao S, Petta S, et al. NT pro BNP plasma level and atrial volume are linked to the severity of liver cirrhosis. PLoS One. 2013; 8(8): e68364, doi: 10.1371/journal.pone.0068364, indexed in Pubmed: 23940514.

17. Epstein SK, Freeman RB, Khayat A, et al. Aerobic capacity is associated with 100-day outcome after hepatic transplantation. Liver Transpl. 2004; 10(3): 418-424, doi: 10.1002/It.20088, indexed in Pubmed: 15004771.

18. Dharancy S, Lemyze M, Boleslawski E, et al. Impact of impaired aerobic capacity on liver transplant candidates. Transplantation. 2008; 86(8): 1077-1083, doi: 10.1097/TP.0b013e318187758b, indexed in Pubmed: 18946345. 
19. Prentis JM, Manas DMD, Trenell MI, et al. Submaximal cardiopulmonary exercise testing predicts 90-day survival after liver transplantation. Liver Transpl. 2012; 18(2): 152-159, doi: 10.1002/It.22426, indexed in Pubmed: 21898768.

20. Galas M, Główczyńska R, Wasilewicz M, et al. Kardiomiopatia wątrobowa i zespół wątrobowo-płucny u pacjenta kwalifikowanego do transplantacji wątroby. Folia Cardiol. 2015; 10(3): 210-213.

21. Cranney GB, Lotan CS, Dean L, et al. Left ventricular volume measurement using cardiac axis nuclear magnetic resonance imaging.
Validation by calibrated ventricular angiography. Circulation. 1990; 82(1): 154-163, indexed in Pubmed: 2364511.

22. Lawton JS, Cupps BP, Knutsen AK, et al. Magnetic resonance imaging detects significant sex differences in human myocardial strain. Biomed Eng Online. 2011; 10: 76, doi: 10.1186/1475-925X-10-76, indexed in Pubmed: 21859466.

23. Zardi EM, Zardi DM, Chin D, et al. Cirrhotic cardiomyopathy in the preand post-liver transplantation phase. J Cardiol. 2016; 67(2): 125-130, doi: 10.1016/j.jjcc.2015.04.016, indexed in Pubmed: 26074443. 